кандидат педагогічних наук, викладач вищої категорії, викладач-методист (Прилуцький гуманітарно-педагогічний коледж імені І. Я. Франка) natashagrona@ukr. net ORCID: 0000-0003-2578-2865

\title{
ФОРМУВАННЯ У МОЛОДШИХ ШКОЛЯРІВ УМІННЯ ПЕРЕКОНУВАТИ Й АРГУМЕНТУВАТИ В КОНТЕКСТІ ІДЕЙ В. О. СУХОМЛИНСЬКОГО (НА ПРИКЛАДІ ЕПІСТОЛЯРНИХ ТЕКСТІВ)
}

У статті розглянуто проблему формування в учнів молодшого шкільного віку уміння переконувати й аргументувати крізь призму педагогічних поглядів В. О. Сухомлинського. У публікачї визначено окремі аспекти текстової діяльності на уроках української мови в ході створення епістолярних текстів. Автор доводить думку, щзо особливої актуальності, значущьсті та важливості набувають концептуальні положення В. Сухомлинського щзодо формування комунікативної компетентності учнів, навчання української мови обов'язково повинно мати практичне спрямування-мати вихід у живе мовленнєве спілкування, епістолярні тексти знайомлять дітей з елементарними правилами логіки і формують уміння застосовувати їх у повсякденному житті.

Ключові слова: уміння аргументувати й переконувати, епістолярний стиль, учні молодшого шкільного віку.

Постановка проблеми. Необхідною умовою формування соціально активної й духовно багатої особистості $\epsilon$ оволодіння мовою як засобом спілкування. Відповідно до Державного стандарту початкової загальної освіти курс української мови передбачає, насамперед, не системну лінгвістичну освіту, а достатній мовленнєвий розвиток і містить чотири змістові лінії - комунікативну, яка $\epsilon$ домінувальною, лінгвістичну, соціокультурну й діяльнісну. Тому нова парадигма початкової освіти вимагає включити до змісту освіти не тільки засвоєння знань і формування мовних умінь, а розвиток мовленнєвого досвіду їхнього застосування, тобто навчання української мови обов'язково повинно мати практичне спрямування - мати вихід у живе мовленнєве спілкування, навчальний дискурс на уроці, де вміння переконувати співрозмовника, правильно й красиво говорити, привертати увагу й здобувати довіру слухачів особливо потрібне. Володіння мистецтвом слова - одна з умов для досягнення успіху в багатьох професіях. Питання мови - питання майстерності. Не лише письменникам, а й пересічним громадянам потрібно, дотримуючись найточнішого слововживання, збагачувати свій словниковий запас, дбати про те, щоб мова була добірною, барвистою. Людина, яка говорить грамотно й переконливо, викликає повагу й довіру.

Аналіз останніх досліджень і публікацій. Уміння аргументувати й переконувати пов'язано 3 історією Стародавнього Сгипту, Ассирії, Вавилона. Однак батьківщиною вчення про культуру мовлення вважається Еллада й, передусім, Аттика як один із ії полісів, у якій уперше з'явилися систематизовані праці з теорії ораторського мистецтва. Розроблення й упровадження сучасних інформаційних технологій в усі сфери життєдіяльності суспільства посилило увагу до мовленнєвого впливу, причому як на публічному, так і на міжособистісному рівні. Як підкреслюється фахівцями з риторики (Н. Голуб, Т. Ладиженська, Л. Мацько, О. Мацько, Н. Михайличенко, О. Семеног, В. Стовпець та ін.) проблема розвитку мовленнєвої діяльності учнів, їхньої комунікативної компетентності $є$ однією 3 найбільш актуальних у теорії і практиці навчання української мови і дає підстави зробити висновок: мистецтва спілкуватися - це шлях до порозуміння з людьми, упевненості в собі та професійного зростання. Особливої значущості в цьому аспекті постає аналіз концептуальних положень методичного доробку В. Сухомлинського, який актуалізував вектор контакту, розуміння позиції іншої людини, узгодженості рішень тощо - тобто як людина уміє спілкуватися.

Мета статті - проаналізувати шляхи формування у молодших школярів уміння переконувати й аргументувати, схарактеризувати методичне забезпечення уроків української мови під час роботи над епістолярними текстами в контексті лінгводидактичної спадщини В. Сухомлинського.

Виклад основного матеріалу дослідження. Сфера використання епістолярного стилю мови не має чітко окреслених меж - це побут, інтимне життя, виробництво, політика, наука, мистецтво, справоведення (справочинство) [1: 295]. Основне призначення епістолярного стилю - обслуговувати заочне, у формі листів, спілкування людей у всіх сферах їхнього життя. Листи - це писемно оформлені монологи, звернені до певної особи (чи осіб). За тематикою і змістом листи можуть бути найрізноманітнішими залежно від сфери їхнього застосування та інтересів адресатів: офіційне (службове) та неофіційне (приватне). Окрім листів, до епістолярного стилю відносять щоденники, 
мемуари, записники, нотатки, календарі. Листи виконують такі функції: комунікативну, ретранслятивну, повідомлювальну.

Мова листів членується на дві частини: соціально-етичну (звертання, початок, дата, місце, привітання, поздоровлення, подяка і прощання, побажання, сподівання, підпис) та основний зміст листа, викладений мовними засобами розмовного стилю завжди індивідуально.

Мова, як засіб спілкування, постійно шукає нові форми оптимальної передачі думки, будучи своєрідним барометром суспільного розвитку, чутливо реагує на найменші зміни в усіх сферах життя. Засоби масової інформації, реклама, ділове спілкування, наука, література є основними джерелами збагачення мови. За останні п'ять років допоміжний сервіс до основної голосової послуги служби коротких повідомлень (Short Message Service, SMS) перетворився в популярний інструмент спілкування.

SMS (англ. Short Message Service - служба коротких повідомлень) - популярна технологія, 3 можливістю обміну інформацією в будь-якому місці і в будь-який час за допомогою стільникового зв'язку, а зараз, завдяки розширенню сервісу послуг, стала можлива відправка повідомлень через Інтернет.

SMS- та MMS- повідомлення загалом зберегли класичну структуру звичайного листа. Початок теж містить етичні формули з вітанням (рідше - звертанням), установлення контакту з адресатом. В основній частині закладено інформацію, фактичний матеріал, те, задля чого надсилалося повідомлення. Завершальна частина має вигляд мовних етикетних формул (прощання, вибачення, побажання тощо). Але часто зміст таких листів має суттєві мовленнєві недоліки й огріхи.

Одним з ефективних засобів вирішення окресленої проблеми є глибоке вивчення, систематизація й узагальнення досвіду виокремлення впливового потенціалу епістолярної спадщини В. Сухомлинського, оскільки листи, їхній зміст відображають усю багатогранність духовності педагога-гуманіста. Окрім того, вони $є$ першоджерелами рецепції внутрішнього світу індивіда. Епістолярна спадщина видатного педагога - це оригінальний здобуток, індивідуальна особливість розуміння процесу виховання, переконання й аргументації на морально-етичну сферу дитини, його ставлення до найвищих національних, соціальних, особистісних вартостей людини i суспільства. Епістолярій педагога багатогранний і надзвичайно цікавий зі стилістичного погляду, адже він уміщує родинно-побутове листування, дружне, приватно-ділове, офіційно-ділове, літературознавче та публіцистичне, записники, щоденники, нотатки.

Епістолярно-педагогічний твір В. Сухомлинського "Листи до сина" репрезентований 22 листами, у яких найбільш повно простежується його педагогічний талант, характер, спосіб мислення. Уже перший лист занурює читача в особистісну атмосферу діалогу батька 3 сином, у якій будуть знаходитись упродовж усього листування син і читачі, де педагог використовує комплекс методів звертання до свідомості вихованця (метод переконання, метод прикладу), які грунтуються на механізмах ідентифікації і наслідування.

Тексти листів - своєрідні публіцистичні "трактати": "Ти спонукаєш мене писати справжні трактати. Спершу про дружбу і кохання, потім - про жіночість, тепер ти просиш сказати батьківське слово про красу. Ну, що ж, я скажу, тільки нехай мої слова залишаться у твоій свідомості на все життя" [2: 633634]. Містять листи й рекомендації для спілкування: "Учись сперечатися", - звертається він до сина. "Добре, що ти сперечаєшся зі мною" [2: 593].

У текстах листів автор не тільки фіксує істинні факти, але й доводить, чому це положення істинне чи хибне, у чому полягає його доцільність або недоцільність. Цей спосіб інтелектуальної діяльності називають аргументацією.

Аргументацію можна визначити як спосіб міркування, який складається із доведення і спростування, у ході яких формується переконання в істинності чи хибності якогось положення як у самого автора так і у опонентів.

У "Листах до сина" ми можемо аргументацію розглядати не просто як процедуру обгрунтування, а й як сукупність аргументів для підтримки тез. Наприклад, як В. Сухомлинський організовував свій робочий день: "Протягом тридцяти років я починаю свій робочий день о 5 годині ранку, працюю до восьмої години. Тридцять книжок з педагогіки та понад триста інших наукових праць - усе це написано 3 5 до 8 години ранку" [2: 649].

Зміст кожного листа має повчальний характер, тому містить значну кількість спонукальних речень, що є характерною ознакою всіх творів педагога ("Не йди на компроміс із власною совістю, тільки так можна викувати характер"). Визначальними для листування є словосполучення, уживані для спонукання адресата до певної дії, поведінки (запиши до своєї записної книжки; уяви собі; задумайся, сину; прагни досконалості); питальні речення ("Навіщо я пишу тобі про це, сину?"). Кінцева формула прощання має декілька частин, у яких традиційно висловлено побажання й поради.

Услід за В. Сухомлинським, сучасні уроки української мови покликані навчити учнів працювати в епістолярному стилі, зокрема занурюватися в природу ситуації, навчаючись мотивовано, грамотно, доречно застосовувати теоретичні знання про лінгвістичні одиниці в мовленнєвій практиці. 
Тактика аргументації - це основа будь-якого переконання. Вдало дібрані факти на захист певної думки можуть мати на слухача значний вплив і сприяти досягненню мети мовця. Вибудуваний за цими правилами текст містить елементи, які передбачають емоційний і раціональний відгук читача. Уміння впливати на аудиторію є складником комунікативної компетентності, воно необхідне для різних видів діяльності. Адресати інтерпретують зміст тексту, виходячи з власних установок, життєвого досвіду, впливу попередніх текстів, тому реакція досить часто буває несподіваною, непередбачуваною для автора. Автори листів можуть тільки припускати про можливу реакцію адресата на їхні звертання, тому контролювати емоційний фон одержувачів листів вони не можуть. Отже, автору потрібно навести аргументи, які могли б бути витлумачені як можна ближче до змісту, який вкладає в них він сам. Листи, зміст яких має переконувати, містять аргументи, що переважно є раціональними. Психологи дають численні поради тим, хто хоче зробити своє висловлювання більш переконливим і пропонують три поширені схеми (методи) переконання. Перша схема - метод лінійного викладу раціональних аргументів (коли другий за силою аргумент уміщують на початку ланцюжка, найсильніший - у кінець, інші розташовуються між ними). Друга - метод порівняльних переваг (переконання в тому, що нова пропозиція значно краща за попередню). Метод мотивації поєднує в собі вирішення проблеми i мотивацію слухачів (вони отримують наочне уявлення про те, у чому полягає їхня вигода) [3].

Поділ стратегії переконання на аргументативну й агітаційну виділяє в аргументативній стратегії наступні тактики: порівняльний аналіз, вказівка на перспективи, обгрунтовані оцінки, ілюстрування. Тільки обгрунтоване оцінювання може бути прийняте в тексті листа як аргумент. Автори листів на захист найчастіше використовують раціональне оцінювання нормативного характеру: правильно, так не буває, краще за все, ие високий результат і т. ін. Емотивність оцінюванню надає використання розмовних слів або мовних образних засобів. Тактика обгрунтованого оцінювання, як правило, супроводжується аргументацією, яка або передує оцінюванню, або слідує за нею як обгрунтування) [4].

Тактика ілюстрування спирається на реальні факти (згадка події, що сталася з включенням статистичних даних, конкретних імен, назв і т. ін.) і приклади (одна із схожих подій, що підтверджує висловлену думку). При цьому фактами і прикладами можуть бути посилання на світовий та історичний досвід, висловлювання авторитетних людей, а також прислів'я, афоризми, беззаперечні твердження. Епістолярна спадщина В. Сухомлинського заслуговує на увагу - як основа формування комунікативної компетентності, коли шкільна освіта модернізується й удосконалюється. Комунікативна практика, про яку багато говорив і методично обгрунтував учений-методист, має пронизувати більшу частину змістового наповнення уроку, усіх його компонентів - теоретичного, практичного й методичного, адже це забезпечує розвиток риторично-комунікативних умінь на основі мовних і мовленнєвих умінь i навичок, практичне оволодіння мистецтвом слова. Наприклад, пропонуємо фрагмент уроку, де представлено роботу над створенням листа-переконання. Учитель: Часто ми бачимо ситуації, які нам не подобаються, $і$ в нас виникає запитання: щзо ми можемо зробити, щзоби змінити ияю ситуацію? Недостатньо просто жалітись один одному. Більи продуктивним є звернення до компетентної особи, яка має достатньо влади, щцоби змінити цุю ситуацію. Якщо ми поговоримо з нею переконливо, то, можливо, це принесе нам певну користь. Проте один із найбільш потужних засобів, щзо ми маємо, є здатність написати. Лист-переконання не тільки дає можливість уточнити $і$ ще раз обдумати наші аргументи, але він також є доказом того, щуо ми справді поскаржилися (звернулися з клопотанням). Якщуо у вас є бажання продовжити щчось зробити, щчоб вирішити цฺю проблему, ией лист буде важливим доказом. Сьогодні ми почнемо нашу роботу з перегляду двох листів, які були написані з метою переконати. Прочитайте изі листи і виділіть аргументи (докази), які зроблять изі листи ефективними, щзоб учні, які їх написали, досягли результату.

\section{Шановний пане директор!}

Як Ви знаєте, наш клас вивчав навколишнє середовище й те, щэо ми можемо вдіяти, щэоб наявних ресурсів нашої планети вистачило надовго. Одна з речей, яку, ми впевнені, треба зробити, ие змусити учнів нашої школи розділяти сміття, зокрема, папір, пляшки з-під соку, поліетилен. У школі півроку стоїьь контейнер для макулатури та для батарейок $і$ акумуляторів. Небагато, але є учні в нашому класі, які сортують удома сміття.

Учорашнє сміття з'являсться у вигляді нових товарів, зокрема, лінолеум, тканина, газетний папір, технічний і покрівельний картон (руберойд), сантехнічні труби, вироби з пластмаси, а з перероблених шин виготовляють килимки для підлоги й підошву для взуття, покриття для тенісних кортів. Чому б не збирати?

Ми переконані, шьо ситуацію зі сміттям у нашому місті можна і потрібно вирішувати. Що для цього потрібно? Щоб чистота нашого міста стала не тільки необхідністю, а трендом, звичним $i$ присмним явищем! А для цьього ми можемо разом з батьками попрацювати на "суботнику", щуоб виготовити контейнери для роздільного збору сміття. І почати ие з нашої школи. Навіть поети почали говорити про те, щзо треба не засмічувати Землю:

Хай річка плаче не слізьми, 
Земля від бруду не страждає,

А ми залишимось людьми,

I будем землю доглядати!

Вамі учні 4 А класу

Шановний Сергію Івановичу!

Так хочеться, щоб подвір'я нашої школи потопало в зелені. Це не тільки красиво, але й корисно: зелені насадження значно зменшують наявність пилу й диму в повітрі, працюють як фільтри.

Вони впливають на тепловий режим, вологість і рух повітря, а також на здоров'я школярів та мешканців мікрорайону.

Окрім иього, шкільне подвір'я - це також місие відпочинку та прогулянок для молодих мам з дітьми, людей похилого віку і мешкканців прилеглих будинків.

Тому пропонусмо очистити прилеглу територію школи від сміття, посадити дерева та розбити клумби. Саджаниі дерев можна попросити в місиевому лісництві, а насіння квітів принесуть учні. А ще можна започаткувати Алею випускників школи різних років. Висаджене випускником дерево - дуже доречний подарунок рідній школі.

Посаджені дерева міџнітимуть і радуватимуть учителів та учнів, жителів сусідніх будинків, котрі приходитимуть у вихідні на шкільне подвір'я відпочити.

Ваші учні 4 А класу

Потім аналізуємо зразки листів-переконань. Учні під керівництвом учителя виділяють структурні компоненти листа, визначають його мету, докази і дають відповіді на такі запитання:

У чому полягає проблема?

Яким є рімення, яке ви пропонуєте?

Хто може реалізувати ие рімення?

Також учні визначають основні характеристики листів: добре структуровані, логічні, не мають орфографічних помилок, переконливі, мають цікаві ідеї, звучать таким чином, що їхні автори знають, чого вони хочуть, і можуть грунтовно довести це.

Висновки і перспективи подальших наукових розвідок. На сучасному етапі модернізації шкільної мовної освіти особливої актуальності, значущості та важливості набувають концептуальні положення В. Сухомлинського щодо формування комунікативної компетентності учнів, а саме розвитку риторичного потенціалу учнів молодшого шкільного віку. Епістолярні тексти знайомлять дітей 3 елементарними правилами логіки i формують уміння застосовувати їх у повсякденному житті. 3 прагматичного погляду побудова епістолярного тексту $є$ реалізацією конструктивно-генеративної стратегії, яка передбачає, що текст має формуватися відповідно до чітко визначеного комунікативного завдання. Подальших наукових досліджень потребують зміст, структура і технологія формування вміння переконувати й аргументувати на прикладі епістолярних текстів в учнів основної школи.

\section{СПИСОК ВИКОРИСТАНИХ ДЖЕРЕЛ ТА ЛІТЕРАТУРИ}

1. Мацько Л. І. Стилістика української мови : [підруч.] / Л. І. Мацько, О. М. Сидоренко, О. М. Мацько; за ред. Л. І. Мацько. - К. : Вища школа, 2003. - 462 с.

2. Сухомлинський В. О. Листи до сина / В. О. Сухомлинський // Вибрані твори в 5-ти томах. - Т. 3. - К. : Рад. школа, 1977. - С. 583-657.

3. Вердербер Р. Communicate! Психология общения / Р. Вердербер, К. Вердербер. - СПб., 2007 -379 с.

4. Голуб Н. Б. Учитель і учні як творці й учасники педагогічного спілкування / Ніна Борисівна Голуб : [зб. наук. пр.]. - Херсон : ХДУ. - Вип. 46. - С. 64-69. (Серія "Педагогічні науки").

\section{REFERENCES (TRANSLATED \& TRANSLITERATED)}

1. Matsko L. I. Stilistika ukrains'koi movy [Stylistics of the Ukrainian language] : [pidruch.] / L. I. Matsko, O. M. Sidorenko, O. M. Matsko ; za red. L. I. Matsko. - K. : Vischa shkola, 2003. - 462 s.

2. SukhomlinskiiV.O. Lysty do syna [Letters to the Son] / V. O. Sukhomlinskii // Vibrani tvori v 5-ti tomakh [Selected Works in 5 Volumes]. - T. 3. - K. : Rad. shkola, 1977. - S. 583-657.

3. Verderber R. Communicate! Psikhologiia obscheniia [Communicate! Psychology of Communication] R. Verderber, K. Verderber. - SPb., $2007-379$ s.

4. Golub N. B. Uchitel' i uchni yak tvortsi i uchasniki pedagogichnogo spilkuvannia [Teacher and Students as Creators and Participants in Pedagogical Communication] : [zb. nauk. pr.] / Nina Borisivna Golub. - Herson : HDU. Vyp. 46. - S. 64-69. (Seriia "Pedagogichni nauki").

\section{Грона Н. В. Формирование у младиих школьников умения убеждать и аргументировать в} контексте идей В. А. Сухомлинского (на примере эпистолярных текстов).

В статье рассмотрена проблема формирования у учащихся младшего школьного возраста умение убеждать и аргументировать сквозь призму педагогических взглядов В. А. Сухомлинского. В публикации определены отдельные аспекты текстовой деятельности на уроках украинского языка в ходе создания 
эпистолярных текстов. Автор доказывает мысль, что особой актуальности, значимости и важности приобретают кониептуальные положения В. Сухомлинского по формированию коммуникативной компетентности учашчихся, обучение украинского языка обязательно должно иметь практическое направление - иметь выход в живое речевое общение, эпистолярные тексть знакомят детей с элементарными правилами логики и формируют умение применять их в повседневной жизни.

Ключевые слова: умение аргументировать и убеждать, эпистолярный стиль, ученики младиего икольного возраста.

\section{Grona N. V. Formation of Primary School Pupils' Abilities to Persuade and to Argue in the Context of Vasyl Sukhomlynsky's Ideas (the Epistolary Text Example).}

The article deals with the problem of forming junior schoolchildren's abilities to persuade and to argue by means of V. Sukhomlynsky's pedagogical views. The definite aspects of the textual activity in the process of making up epistolary texts at Ukrainian lessons have been defined in this publication.

The author proves the idea that Vasyl Sukhomlynsky's conceptual positions concerning the formation of pupils' communicative competence are of great importance, significance and demand; teaching modern Ukrainian must be practically oriented and applied in natural speech practice; epistolary texts introduce the elementary rules of

logic to children and develop their skills to use them in everyday life. The ability to influence audience is considered to be a part of communicative competence, it is necessary for various kinds of activities.

Addressees interpret the content of the text taking into the consideration their own attitudes, life experience and the influence of previous texts. For this reason, reaction can be unexpected and unpredictable for an author.

Authors of letters can only expect the addressees' possible reaction but they cannot control their emotional condition. So it is necessary for an author to give such arguments that could be interpreted as close as possible to the content. The letters which prove the arguments they contain are considered to be rational.

The tactics of an argument is the basis of any belief. Well-chosen facts in the defense of a certain opinion can have a significant influence on a listener and contribute to the achievement of a speaker's goals. The text constructed according to these rules contains the elements that reveal a reader's emotional and rational response. $V$. Sukhomlynsky's epistolary heritage deserves much attention as the basis of forming communicative competence while the school education is modernized and improved.

The communicative practice that was methodologically proved and much spoken about by the methodologist must be used in all the components of the lesson - theoretical, practical and methodical ones, because it ensures the development of rhetorical communicative skills and practical mastering the art of a word on the basis of linguistic and speech skills and habits.

Key words: skills to argue and to persuade, epistolary style, primary school pupils. 